\title{
Towards Iron-Titanium Oxide Nanostructures from Ecuadorian Black Mineral Sands
}

\author{
Karina J. Lagos ${ }^{1,2}$, Bojan A. Marinkovic ${ }^{3, * \mathbb{D}}$, Alexis Debut ${ }^{4} \mathbb{D}$, Karla Vizuete ${ }^{4} \mathbb{D}$, Víctor H. Guerrero ${ }^{2} \mathbb{D}^{\text {, }}$ \\ Emilio Pardo ${ }^{1}$ (D) and Patricia I. Pontón $2, *$ (I)
}

check for

updates

Citation: Lagos, K.J.; Marinkovic, B.A.; Debut, A.; Vizuete, K.; Guerrero, V.H.; Pardo, E.; Pontón, P.I. Towards Iron-Titanium Oxide Nanostructures from Ecuadorian Black Mineral Sands. Minerals 2021, 11, 122. https:// doi.org/10.3390/min11020122

Received: 28 December 2020

Accepted: 22 January 2021

Published: 26 January 2021

Publisher's Note: MDPI stays neutral with regard to jurisdictional claims in published maps and institutional affiliations.

Copyright: (c) 2021 by the authors. Licensee MDPI, Basel, Switzerland. This article is an open access article distributed under the terms and conditions of the Creative Commons Attribution (CC BY) license (https:// creativecommons.org/licenses/by/ $4.0 /)$.
1 Coordination Chemistry Group, Molecular Science Institute, University of Valencia, 46980 Paterna, Spain; karina.lagos@epn.edu.ec (K.J.L.); emilio.pardo@uv.es (E.P.)

2 Department of Materials, Escuela Politécnica Nacional (EPN), Quito 170525, Ecuador; victor.guerrero@epn.edu.ec

3 Department of Chemical and Materials Engineering, Pontifical Catholic University of Rio de Janeiro (PUC-Rio), Rio de Janeiro 22453-900, Brazil

4 Centro de Nanociencia y Nanotecnología, Universidad de Las Fuerzas Armadas (ESPE), Sangolquí 171103, Ecuador; apdebut@espe.edu.ec (A.D.); ksvizuete@espe.edu.ec (K.V.)

* Correspondence: bojan@puc-rio.br (B.A.M.); patricia.ponton@epn.edu.ec (P.I.P.)

\begin{abstract}
Ecuadorian black mineral sands were used as starting material for the production of iron-titanium oxide nanostructures. For this purpose, two types of mineral processing were carried out, one incorporating a pre-treatment before conducting an alkaline hydrothermal synthesis $(\mathrm{NaOH}$ $10 \mathrm{M}$ at $180{ }^{\circ} \mathrm{C}$ for $72 \mathrm{~h}$ ), and the other prescinding this first step. Nanosheet-assembled flowers and nanoparticle agglomerates were obtained from the procedure including the pre-treatment. Conversely, nanobelts and plate-like particles were prepared by the single hydrothermal route. The nanoscale features of the product morphologies were observed by scanning electron microscopy (SEM) and transmission electron microscopy (TEM) analyses. The ilmenite and hematite molar fractions, within the ilmenite-hematite solid solution, in the as-synthetized samples were estimated by Brown's approach using the computed values of unit-cell volumes from Le Bail adjustments of X-ray powder diffraction (XRPD) patterns. The resulting materials were mainly composed of Fe-rich ilmenite-hematite solid solutions (hematite molar contents $\geq 0.6$ ). Secondary phases, which possibly belong to lepidocrocite-like or corrugated titanate structures, were also identified. The current study demonstrated the feasibility of employing Ecuadorian mineral resources as low-cost precursors to synthesize high-added-value nanostructures with promising applications in several fields.
\end{abstract}

Keywords: ilmenite-hematite solid solution; ferrotitaniferous sands; alkaline hydrothermal synthesis; nanosheet-assembled flowers; plate-like particles; nanobelts

\section{Introduction}

Ferrotitaniferous or black mineral sands (BMS) have attracted great attention in a wide range of technological and scientific fields due to their ilmenite-rich content, low cost and availability. This mineral resource is found in secondary ore deposits over the coastlines of several countries, such as Australia [1], Brazil [2], Egypt [3], India [4], and Ecuador [5]. The industrial applications of BMS have been mainly focused on titanium dioxide production [6], and the recovery of iron (Fe) and titanium (Ti) $[7,8]$. On the other hand, there are currently several researches devoted to the potential use of BMS as (i) adsorption agents of heavy metals [9], (ii) photocatalysts for dye degradation [10], and (iii) precursors to synthetize iron-titanium oxide nanostructures (Fe-Ti-NS) [11-14].

Regarding the last topic, Fe-Ti-NS have excelled as multifunctional materials in several areas, such as materials engineering, environmental protection, energy, and medicine [15-23]. The particular properties of Fe-Ti-NS strongly depend on their size, composition, morphology, and crystal structure, which are determined by the precursor and the synthesis conditions. 
The preparation of Fe-Ti-NS has been carried out, so far, by alkaline hydrothermal treatment of unrefined BMS precursors [12-14]. This route is known as a soft-chemistry synthesis since the processing temperatures are below $200{ }^{\circ} \mathrm{C}$, and there is no need for an additional calcination step to crystallize the desired nanostructures. In addition, it has attractive advantages such as easy start-up, low energy consumption, high yield production, and chemically homogeneous products. In turn, long reaction times are usually required, which constitutes the main disadvantage. Therefore, alkaline hydrothermal treatment opens a framework for the preparation of nanostructures with diverse morphologies, such as nanotubes, nanosheets, nanofibers, nanorods, nanobelts, and nanoparticles, in a simple one-step approach. It is worth mentioning that not only BMS have been used as raw minerals for the synthesis of nanostructures, rutile-based mineral sands have also been assessed for the same purpose [24-28]. The Fe-Ti-NS and titania-based nanostructures obtained from these precursors were analogous to those prepared from more expensive, ultrapure chemical reagents [28]. This is of paramount importance from the economic point of view, since BMS precursors could generate savings of almost $80 \%$ related to the cost of high-purity reagents, considering that the price of $\mathrm{TiO}_{2}$ commercial powders is around $\$ 2000 / \mathrm{MT}$, while the price of mineral sands such as rutile is barely $\$ 420 / \mathrm{MT}$ [29] and $\sim$ 100/MT for ilmenite [30].

An overview of the aforementioned studies on the preparation of Fe-Ti-NS from mineral sands is summarized in Table 1, which presents data about (i) mineral precursors, (ii) synthesis conditions and (iii) as-prepared products. Note that the precursors described in the literature exhibited $\mathrm{Fe} / \mathrm{Ti}$ mass ratios below 1.20, due to their low $\mathrm{Fe}_{2} \mathrm{O}_{3} / \mathrm{FeO}$ contents (0.93-38 wt.\%) [12,28], against their high $\mathrm{TiO}_{2}$ contents (42-96 wt.\%) [24,28]. Hence, most of the reported products correspond to titanate-based nanostructures doped with iron. The presence of hematite nanoparticles has also been identified [12,14]. Conversely, there are other less known and explored precursors, such as Ecuadorian BMS, which are fairly attractive due to their particular mineral and chemical compositions. This precursor, from Mompiche location, corresponds to an ilmenite-hematite solid solution $\left(0.6 \mathrm{FeTiO}_{3} \cdot 0.4 \mathrm{Fe}_{2} \mathrm{O}_{3}\right)$, with trace amounts of orthoclase feldspar and zircon. Ecuadorian BMS exhibit an Fe/Ti mass ratio of 2.8 [5]; that is, 2.3 to 280 times higher than the values of the mineral sands presented in Table 1. Besides, the price of Ecuadorian BMS in the local market is very low $(\sim 24 / \mathrm{MT})[31]$.

Hence, the aim of this work is to assess the feasibility of synthesizing Fe-Ti-NS from Ecuadorian BMS through an alkaline hydrothermal treatment, contributing, therefore, in adding value to these mineral sands. The phase composition, morphology, size, Fe/Ti mass ratio, and specific surface area of the as-prepared products were thoroughly studied. 
Table 1. Preparation of Fe-Ti-NS: precursors, synthesis conditions and products.

\begin{tabular}{|c|c|c|c|c|c|c|c|c|c|}
\hline \multicolumn{4}{|c|}{ Precursor } & \multirow{2}{*}{$\begin{array}{l}\text { Synthesis } \\
\text { Conditions }\end{array}$} & \multirow[b]{2}{*}{ Post-Treatment } & \multicolumn{3}{|c|}{ Synthesized Product } & \multirow[b]{2}{*}{ Ref. } \\
\hline Origin & $\begin{array}{l}\text { Crystalline } \\
\text { Phase(s) }\end{array}$ & Fe/Ti Mass Ratio & Pre-Treatment & & & $\begin{array}{l}\text { Chemical } \\
\text { Formula }\end{array}$ & $\begin{array}{l}\text { Crystalline } \\
\text { Phase(s) }\end{array}$ & Morphology & \\
\hline Thailand & Rutile & 0.42 & None & $\begin{array}{l}\mathrm{NaOH} 10 \mathrm{M} \\
120^{\circ} \mathrm{C} \\
72 \mathrm{~h} \\
\text { (Stirring) }\end{array}$ & $\begin{array}{l}\text { Washing with } \mathrm{HCl} \text { and } \\
\text { distilled water; drying } \\
\text { with hot air }\end{array}$ & $\mathrm{H}_{2} \mathrm{Ti}_{\mathrm{x}} \mathrm{O}_{2 \mathrm{x}+1}$ & $\begin{array}{l}\text { Trititanate } \\
\left(\mathrm{H}_{2} \mathrm{Ti}_{3} \mathrm{O}_{7}\right)\end{array}$ & $\begin{array}{c}\text { Layered nanostructures: } \\
\text { Fe-doped } \\
\text { titanate nanofibers } \\
\text { (diameters: } 20-90 \mathrm{~nm} \text {; } \\
\text { length: } 2-7 \mathrm{~mm} \text { ) }\end{array}$ & {$[22,23]$} \\
\hline Russia & $\begin{array}{l}\text { Rutile and quartz } \\
\text { (non-magnetic } \\
\text { fraction) }\end{array}$ & 0.03 & $\begin{array}{l}\text { Magnetic } \\
\text { separation and } \\
\text { milling of } \\
\text { non-magnetic } \\
\text { fraction up to } \\
20-40 \mu \mathrm{m}\end{array}$ & $\begin{array}{c}\mathrm{NaOH} 10 \mathrm{M} \\
110^{\circ} \mathrm{C} \\
24 \mathrm{~h}\end{array}$ & $\begin{array}{l}\text { Washing with distilled } \\
\text { water and } \mathrm{HCl} \text {; drying } \\
\text { at } 90^{\circ} \mathrm{C} \text { for } 12 \mathrm{~h}\end{array}$ & $\begin{array}{c}\mathrm{Na}_{x} \mathrm{H}_{2-x} \mathrm{Ti}_{3} \mathrm{O}_{7} \\
(\mathrm{Fe} / \mathrm{Ti} \text { ratio }=0.09) \\
\text { and } \mathrm{SiO}_{2}\end{array}$ & $\begin{array}{l}\text { Trititanate } \\
\text { and quartz }\end{array}$ & $\begin{array}{l}\text { Layered nanostructures: } \\
\text { Titanate nanotubes } \\
\text { (diameter: } 70-100 \mathrm{~nm} \text {; } \\
\text { length: up to } 4500 \mathrm{~nm} \text { ) }\end{array}$ & [24] \\
\hline Australia & Rutile and anatase & 0.01 & None & $\begin{array}{c}\mathrm{NaOH} 10 \mathrm{M} \\
150^{\circ} \mathrm{C} \\
120 \mathrm{~h} \\
\text { (Stirring) } \\
\end{array}$ & $\begin{array}{l}\text { Washing with } \mathrm{HCl} \text { and } \\
\text { distilled water; } \\
\text { drying RT }\end{array}$ & $\begin{array}{l}\mathrm{Na}_{0.4} \mathrm{H}_{1.6} \mathrm{Ti}_{3} \text { with } \\
(\mathrm{Na}, \mathrm{H})_{2} \mathrm{Ti}_{6} \mathrm{O}_{13} \\
\text { type-defect }\end{array}$ & $\begin{array}{l}\text { Trititanate with } \\
\text { hexatitanate- } \\
\text { type defect }\end{array}$ & $\begin{array}{l}\text { Layered nanostructures: } \\
\text { Titanate nanofibers } \\
\text { (diameter: } 20-50 \mathrm{~nm} \text {; } \\
\text { length: } 10-500 \mu \mathrm{m} \text { ) }\end{array}$ & {$[25,26]$} \\
\hline Australia & Rutile and anatase & Not specified & None & $\begin{array}{c}\mathrm{NaOH} 10 \mathrm{M} \\
150^{\circ} \mathrm{C} \\
72 \mathrm{~h} \\
\text { (Stirring) } \\
\end{array}$ & $\begin{array}{l}\text { Washing with } \mathrm{HCl} \text { and } \\
\text { distilled water; } \\
\text { freeze drying }\end{array}$ & $\begin{array}{l}\mathrm{H}_{2} \mathrm{Ti}_{\mathrm{x}} \mathrm{O}_{2 \mathrm{x}+1} \\
\left(\mathrm{H}_{2} \mathrm{Ti}_{3} \mathrm{O}_{7}\right)\end{array}$ & Tritanate & $\begin{array}{l}\text { Solid nanofibers } \\
\text { (diameter: } 20-50 \mathrm{~nm} \text {; } \\
\text { length: hundreds } \\
\text { of nanometers) }\end{array}$ & [27] \\
\hline Australia & Ilmenite & 1.20 & $\begin{array}{l}\text { Magnetic ball } \\
\text { milling }\end{array}$ & $\begin{array}{l}\mathrm{NaOH} 2 \mathrm{M} \\
120^{\circ} \mathrm{C} \\
2 \mathrm{~h} \\
\text { (Stirring) } \\
\end{array}$ & $\begin{array}{l}\text { Washing; drying at } 90 \\
{ }^{\circ} \mathrm{C} \text { for } 4 \mathrm{~h}\end{array}$ & $\mathrm{FeTiO}_{3}$ & Ilmenite & $\begin{array}{c}\text { Nanoflowers } \\
\text { (diameter: } 1-2 \mu \mathrm{m} \text {; } \\
\text { petal thickness: } 5-20 \mathrm{~nm} \text {; } \\
\text { petal wide: } 100-200 \mathrm{~nm} \text { ) }\end{array}$ & [30] \\
\hline Brazil & $\begin{array}{l}\text { Ilmenite, rutile, } \\
\text { pseudorutile, } \\
\text { and quartz }\end{array}$ & 0.81 & $\begin{array}{l}\text { Milling up to } \\
0.25 \mu \mathrm{m}\end{array}$ & $\begin{array}{l}\mathrm{NaOH} 10 \mathrm{M} \\
130^{\circ} \mathrm{C} \\
70 \mathrm{~h} \\
\text { (Stirring) }\end{array}$ & $\begin{array}{l}\text { Washing with distilled } \\
\text { water; drying at } 80^{\circ} \mathrm{C} \\
\text { for } 5 \mathrm{~h}\end{array}$ & $\begin{array}{c}\mathrm{Na}_{\mathrm{x}-\mathrm{y}} \mathrm{H}_{\mathrm{y}} \mathrm{Ti}_{2-\mathrm{x}} \\
\mathrm{Fe}_{\mathrm{x}} \mathrm{O}_{4} \cdot \mathrm{nH}_{2} \mathrm{O} \\
\text { and } \mathrm{Fe}_{2} \mathrm{O}_{3}\end{array}$ & $\begin{array}{l}\text { Lepidocrocite-like } \\
\text { titanate and small } \\
\text { amounts of } \\
\text { hematite }\end{array}$ & $\begin{array}{l}\text { Layered nanostructures: } \\
\text { Leaf-like titanate } \\
\text { nanosheets (thickness } \\
\quad<30 \mathrm{~nm} \text {; } \\
\text { length }<1 \mu \mathrm{m} \text { ), and } \\
\text { hematite nanoparticles }\end{array}$ & [12] \\
\hline Brazil & Ilmenite, rutile & Not specified & Not specified & $\begin{array}{l}\mathrm{NaOH} 10 \mathrm{M} \\
190^{\circ} \mathrm{C} \\
70 \mathrm{~h} \\
\text { (Stirring) }\end{array}$ & $\begin{array}{l}\text { Washing with distilled } \\
\text { water; drying at } 80^{\circ} \mathrm{C} \\
\text { for } 5 \mathrm{~h}\end{array}$ & $\begin{array}{c}\mathrm{Na}_{x} \mathrm{Fe}_{x} \mathrm{Ti}_{2-x} \mathrm{O}_{4} \\
(92 \%) \\
\mathrm{Fe}_{3} \mathrm{O}_{4}(7 \%) \\
\mathrm{x}=0.76-0.79 \\
(\mathrm{Fe} / \mathrm{Ti} \text { ratio }=0.71)\end{array}$ & $\begin{array}{l}\mathrm{CaFe}_{2} \mathrm{O}_{4} \text { structure } \\
\text { type group and } \\
\text { magnetite }\end{array}$ & $\begin{array}{l}\text { Submicron to micron } \\
\text { crystals with } \\
\text { well-defined facets }\end{array}$ & [13] \\
\hline
\end{tabular}


Table 1. Preparation of Fe-Ti-NS: precursors, synthesis conditions and products.

\begin{tabular}{|c|c|c|c|c|c|c|c|c|c|}
\hline \multicolumn{4}{|c|}{ Precursor } & \multirow{2}{*}{$\begin{array}{l}\text { Synthesis } \\
\text { Conditions }\end{array}$} & \multirow[b]{2}{*}{ Post-Treatment } & \multicolumn{3}{|c|}{ Synthesized Product } & \multirow[b]{2}{*}{ Ref } \\
\hline Origin & $\begin{array}{l}\text { Crystalline } \\
\text { Phase(s) }\end{array}$ & Fe/Ti Mass Ratio & Pre-Treatment & & & $\begin{array}{l}\text { Chemical } \\
\text { Formula }\end{array}$ & $\begin{array}{l}\text { Crystalline } \\
\text { Phase(s) }\end{array}$ & Morphology & \\
\hline Brazil & $\begin{array}{l}\text { Pseudorutile, } \\
\text { ilmenite, hematite, } \\
\text { rutile and quartz }\end{array}$ & 0.90 & $\begin{array}{l}\text { Milling up to } \\
0.8 \mu \mathrm{m}\end{array}$ & $\begin{array}{c}\mathrm{NaOH} 10 \mathrm{M} \\
110,130,150,170,190{ }^{\circ} \mathrm{C} \\
70 \mathrm{~h} \\
\text { (Stirring) }\end{array}$ & $\begin{array}{l}\text { Washing with distilled } \\
\text { water; drying at } 80^{\circ} \mathrm{C} \\
\text { for } 5 \mathrm{~h}\end{array}$ & $\begin{array}{l}\mathrm{Na}_{x-y} \mathrm{H}_{\mathrm{y}} \mathrm{Ti}_{2-\mathrm{x}} \mathrm{Fe}_{\mathrm{x}} \mathrm{O}_{4} \\
\quad \text { and } \mathrm{Fe}_{2} \mathrm{O}_{3}\end{array}$ & $\begin{array}{l}\text { Lepidocrocite-like } \\
\text { titanate } \\
\text { and hematite }\end{array}$ & $\begin{array}{l}\text { Layered nanostructures: } \\
\text { Fe-doped titanate } \\
\text { nanosheets } \\
\left(110,130 \text { and } 150{ }^{\circ} \mathrm{C}\right) \\
\text { Titanate nanoribbons } \\
\text { (Fe-free })+ \text { Fe-doped } \\
\text { titanate nanosheets and } \\
\text { hematite nanoparticles } \\
\left(170 \text { and } 190^{\circ} \mathrm{C}\right)\end{array}$ & [14] \\
\hline Brazil & Not specified & Not specified & Milling & $\begin{array}{l}\mathrm{NaOH} 10 \mathrm{M} \\
130^{\circ} \mathrm{C} \\
70 \mathrm{~h} \\
\text { (Stirring) }\end{array}$ & $\begin{array}{l}\text { Washing with distilled } \\
\text { water and } \mathrm{HCl} \text {; drying } \\
\text { at } 80^{\circ} \mathrm{C} \text { for } 5 \mathrm{~h}\end{array}$ & $\mathrm{H}_{\mathrm{x}} \mathrm{Ti}_{2-\mathrm{x}} \mathrm{Fe}_{\mathrm{x}} \mathrm{O}_{4} \cdot \mathrm{nH}_{2} \mathrm{O}$ & $\begin{array}{l}\text { Lepidocrocite-like } \\
\text { titanate }\end{array}$ & $\begin{array}{c}\text { Layered nanostructures: } \\
\text { Fe-doped titanate } \\
\text { nanosheets, composed of } \\
\sim 10 \text { stacked layers } \\
\text { (thickness of each layer } \\
<1 \mathrm{~nm} \text { ) }\end{array}$ & [32] \\
\hline Brazil & $\begin{array}{l}\text { Rutile, anatase, } \\
\text { and zircon }\end{array}$ & 0.02 & $\begin{array}{l}\text { Milling 0, 30, 60, } \\
90 \mathrm{~min}\end{array}$ & $\begin{array}{l}\mathrm{NaOH} 10 \mathrm{M} \\
140^{\circ} \mathrm{C} \\
70 \mathrm{~h} \\
\text { (Stirring) }\end{array}$ & $\begin{array}{l}\text { Washing with distilled } \\
\text { water; drying at } 80^{\circ} \mathrm{C} \\
\text { for } 5 \mathrm{~h}\end{array}$ & $\begin{array}{l}\mathrm{Na}_{2-x} \mathrm{H}_{\mathrm{x}} \mathrm{Ti}_{n} \mathrm{O}_{2 \mathrm{n}+1} \\
(\mathrm{Fe} / \mathrm{Ti} \text { ratio }=0.01)\end{array}$ & $\begin{array}{l}\text { Trititanate } \\
(60 \mathrm{~min}) ; \\
\text { pentatitanate } \\
\text { and trititanate } \\
(0,30,90 \mathrm{~min})\end{array}$ & $\begin{array}{c}\text { Layered nanostructures: } \\
\text { Nanotubes }(60 \mathrm{~min}) \\
\text { (diameter }<10 \mathrm{~nm} ; \\
\text { length: several hundreds } \\
\text { of } \mathrm{nm}) \\
\text { Nanofibers }(0,30, \\
90 \mathrm{~min})(\text { diameter: } \\
20-50 \mathrm{~nm} \text {; } \\
\text { length: several hundreds } \\
\text { of } \mathrm{nm})\end{array}$ & [28] \\
\hline
\end{tabular}




\section{Materials and Methods}

\subsection{Synthesis of Fe-Ti-NS from Ecuadorian BMS}

Firstly, the sands were ground in a planetary mill (Retsch PM 400, Hann, North Rhine-Westphalia, Germany) at $300 \mathrm{rpm}$ for $9 \mathrm{~min}$. The milling was carried out with a 20:1 ball-to-sand mass ratio, using stainless steel jars and balls without the use of any liquid. The resulting powder (milled BMS), with a particle size between 0.5 and $30 \mu \mathrm{m}$ as evaluated by scanning electron microscopy (SEM) (Mira 3 Tescan, Brno, South Moravian, Czech Republic), was used as precursor for the synthesis of Fe-Ti-NS.

Two types of mineral processing were performed to synthesize Fe-Ti-NS, and their schematic representation is depicted in Figure 1. Both procedures were based on alkaline hydrothermal synthesis, but one incorporated the following pre-treatment. A determined amount of milled sand $(3.5 \mathrm{~g})$ was treated with $350 \mathrm{~mL}$ of $\mathrm{NaOH} 10 \mathrm{M}$ at $180^{\circ} \mathrm{C}$ for $28 \mathrm{~h}$ under constantly stirring. Since the color of the resultant dispersion remained black, as the starting BMS, it was subjected to a long-term aging to promote a severe precursor transformation. Therefore, the dispersion was poured into a beaker and kept for 28 days at room temperature (RT) without stirring. To avoid evaporation of the $\mathrm{NaOH}$ solution, the beaker was covered with a plastic sealing film. Then, the dispersion was agitated during 5 more days. Thereby, the resulting pre-treated precursor was obtained as a suspension. The powder was recovered by centrifugation and dried at RT.

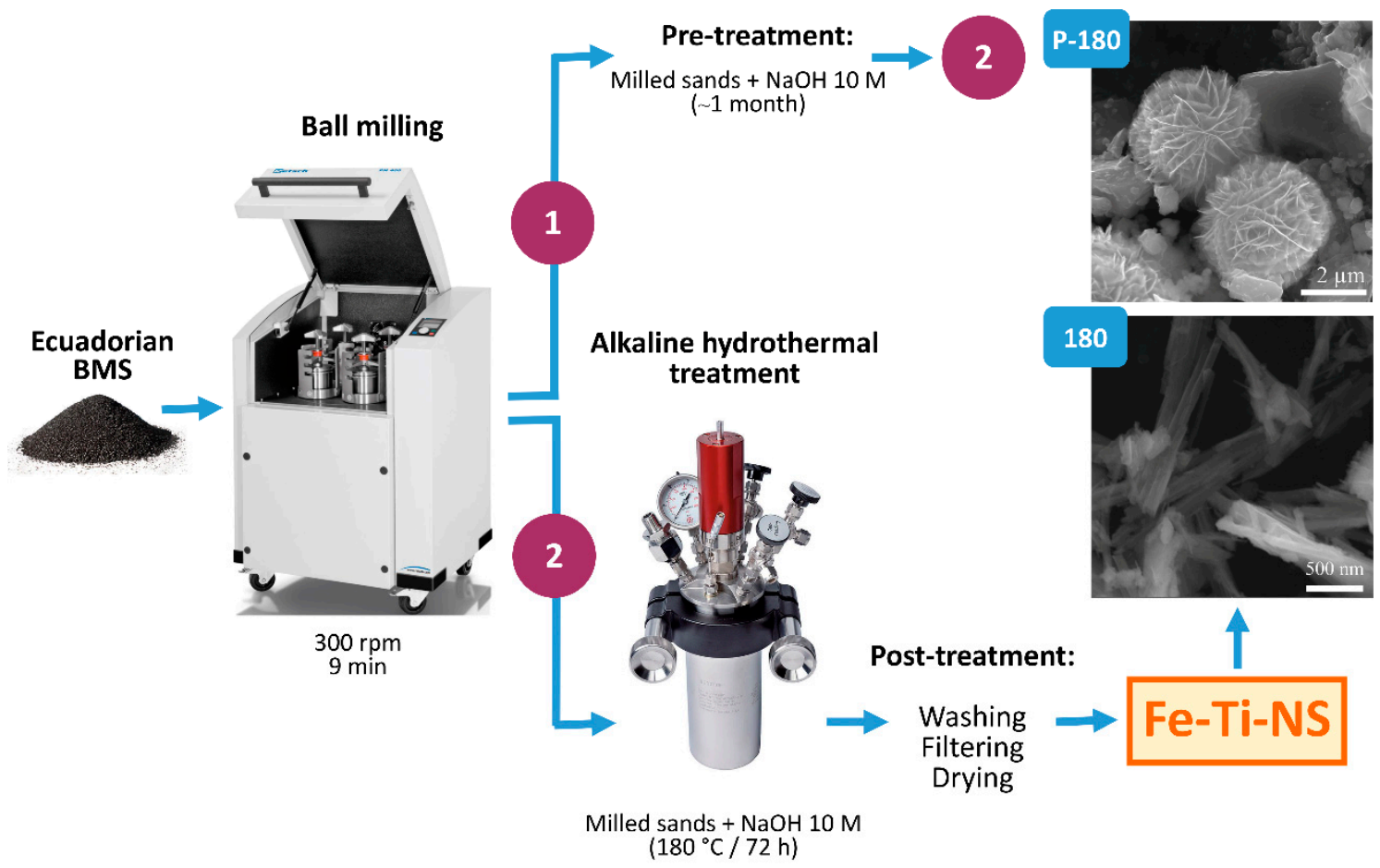

Figure 1. Schematic representation of Ecuadorian black mineral sands (BMS) processing to synthetize Fe-Ti-NS.

In the alkaline hydrothermal synthesis, $1.75 \mathrm{~g}$ of precursor (pre-treated or not) and $350 \mathrm{~mL}$ of $\mathrm{NaOH} 10 \mathrm{M}$ were added into a reactor (Berghof BR-500, Eningen, Baden-Württemberg, Germany) (filling factor of 0.7 ). The reactants were continuously stirred for $72 \mathrm{~h}$ at $180^{\circ} \mathrm{C}$. Afterwards, the reactor was allowed to cool to RT and the as-prepared materials were centrifugally separated and washed with distilled water repeatedly up to $\mathrm{pH} \sim 9$. The resulting Fe-Ti-NS were recovered by filtration and dried at RT. The as-obtained powders were denoted P-180 and 180, for pre-treated and no pre-treated samples, respectively. 


\subsection{Characterization of $\mathrm{Fe}-\mathrm{Ti}-\mathrm{NS}$}

The phase composition of the precursor (milled Ecuadorian BMS) and the as-synthesized powders was determined by X-ray powder diffraction (XRPD) (Bruker D2 Phaser Diffractometer, Karlsruhe, Baden-Württemberg, Germany), operating with $\mathrm{Cu} \mathrm{K} \alpha$ radiation at $10 \mathrm{~mA}$ and $30 \mathrm{kV}$, in a $2 \theta$ range from $10^{\circ}$ to $80^{\circ}$ with steps of $0.02^{\circ}$ ( $2 \mathrm{~s}$ per step). The phase identification was performed with EVA software (version 4.1) and the PDF2 ICDD database.

The Le Bail method was used, applying the software Topas (version 5). Mean crystallite sizes and unit-cell parameters were obtained by this approach.

Fe-Ti-NS morphology and semiquantitative elemental composition were evaluated by SEM and energy dispersive X-ray spectroscopy (EDS), respectively. These analyses were carried out in a microscope (Tescan Mira 3, Brno, South Moravian, Czech Republic) equipped with a Schottky field emission gun at $20 \mathrm{kV}$ accelerating voltage. EDS was performed in a SEM chamber, using a detector (Bruker X-Flash 6I30, Karlsruhe, BadenWürttemberg, Germany) with a $123 \mathrm{eV}$ resolution at Mn K $\alpha$. The Fe-Ti-NS were also characterized by transmission electron microscopy (TEM). The images were acquired in a microscope (FEI Tecnai G2 Spirit Twin, Eindhoven, North Brabant, The Netherlands) operating at $80 \mathrm{kV}$. TEM specimens were prepared by ultrasonic dispersion of a small amount of powder in ethanol, and then dropping the dispersion onto a holey carbon film supported by a copper grid.

The specific surface area was measured by $\mathrm{N}_{2}$ adsorption through the Brunauer-EmmettTeller (BET) approach, using a gas sorption analyzer (Quantachrome Instruments Novatouch LX-1, Boynton Beach, FL, USA). The samples were pre-treated at $100{ }^{\circ} \mathrm{C}$ under vacuum of 5 Torr, for $24 \mathrm{~h}$. The correlation coefficients were higher than 0.9999 for all the analyses.

\section{Results}

After alkaline hydrothermal treatment, the as-prepared products from both processing routes showed significant changes in their color; i.e., reddish and brown powders were obtained for P-180 and 180 samples, as can be seen in Figure 2b,c, respectively. The change of color is an indirect proof of chemical purification of BMS (see Figure 2a) since pure ilmenite is a semiconductor with a band gap of approximately $2.5 \mathrm{eV}$, while on the other side of ilmenite-hematite solid solution, hematite presents a band gap of $2.2 \mathrm{eV}$ [33].
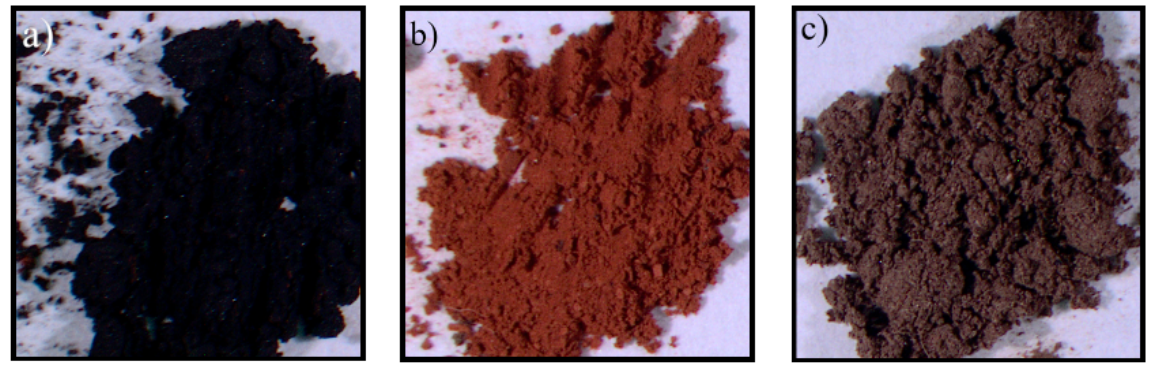

Figure 2. (a) Milled Ecuadorian BMS, (b) P-180 and (c) 180 powders.

\subsection{XRPD Analysis}

The XRPD patterns of the precursor (milled BMS) and of the as-prepared powders (P-180 and 180) are shown in Figure 3, with the corresponding Le Bail adjustments for ilmenite-hematite solid solution (IH-SS). The space group $(R-3)$ and a unit-cell of pure ilmenite $\left(\mathrm{FeTiO}_{3}\right)$ were used as the starting model for refinement of the unit-cell parameters of the phases within the ilmenite-rich part of the ilmenite-hematite solid solution. The space group used for the hematite-rich part of the solid solution was $R-3 c$. The values of the unit-cell volumes and mean crystallite sizes for ilmenite-hematite solid solution are listed in Table 2. 


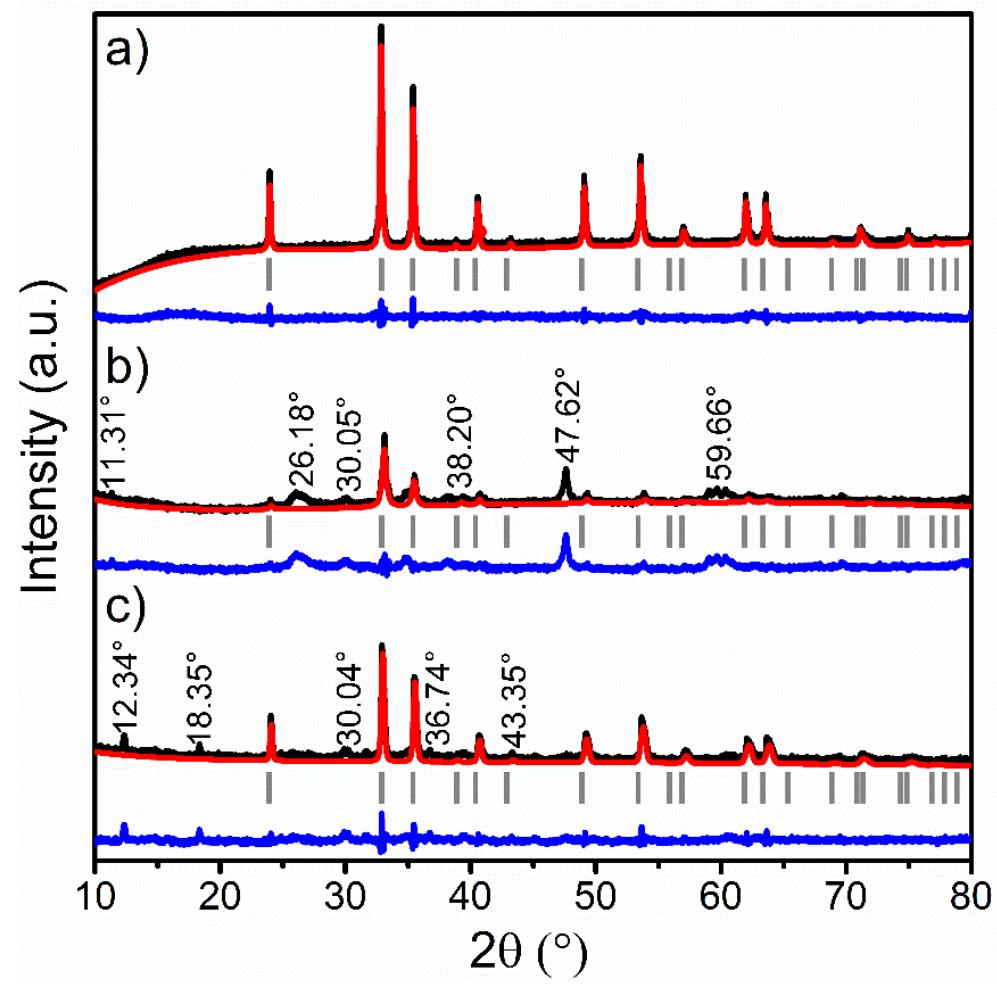

Figure 3. XRPD patterns of (a) milled BMS precursor, and (b) P-180 and (c) 180 powders, with the corresponding Le Bail refinements. Experimental pattern (black), calculated pattern (red) and difference plot (blue). Gray vertical bars correspond to IH-SS, PDF 01-070-8143.

Table 2. Unit-cell volumes and mean crystallite sizes of the phases within ilmenite-hematite solid solution for milled BMS, and P-180 and 180 powders.

\begin{tabular}{ccc}
\hline Sample & Unit-Cell Volume $\left(\AA^{\mathbf{3}}\right)$ & Mean Crystallite Size $(\mathbf{n m})$ \\
\hline Milled BMS & $308.51(7)$ & $58.80(0.9)$ \\
P-180 & $305.76(7)$ & $25.03(1.9)$ \\
180 & $306.47(7)$ & $101.01(7.6)$ \\
\hline
\end{tabular}

The XRPD pattern of the milled BMS precursor (Figure 3a) corresponds to an IH-SS, as reported in our previous study [5]. The XRPD pattern of P-180 powder (Figure 3b) presented few characteristic diffraction lines of the ilmenite-rich precursor (for example, those at $33.13^{\circ}$ and $35.53^{\circ}$ ), but also weaker and broad diffraction lines at $11.31^{\circ}, 26.18^{\circ}$, $30.05^{\circ}, 38.20^{\circ}, 47.62^{\circ}$ and $59.66^{\circ} 2 \theta$. With regard to the XRPD pattern of 180 powder (Figure 3c), it resembled that of the precursor, nevertheless it exhibited new low intensity peaks at $12.34^{\circ}, 18.35^{\circ}, 30.04^{\circ}, 36.74^{\circ}$, and $43.35^{\circ} 2 \theta$. In both synthetized samples, neither of these new diffraction lines can be identified within IH-SS.

\subsection{SEM-EDS Analysis}

SEM images of milled BMS are presented in Figure $4 a, b$. The powder consists of micron-size agglomerates built from nano- to micrometer particles with irregular shapes. Iron and titanium were confirmed by EDS analysis to be the major elements, with an $\mathrm{Fe} / \mathrm{Ti}$ mass ratio of $\sim 3.1$ (Supplementary Materials, Figure S1 and Table S1). 

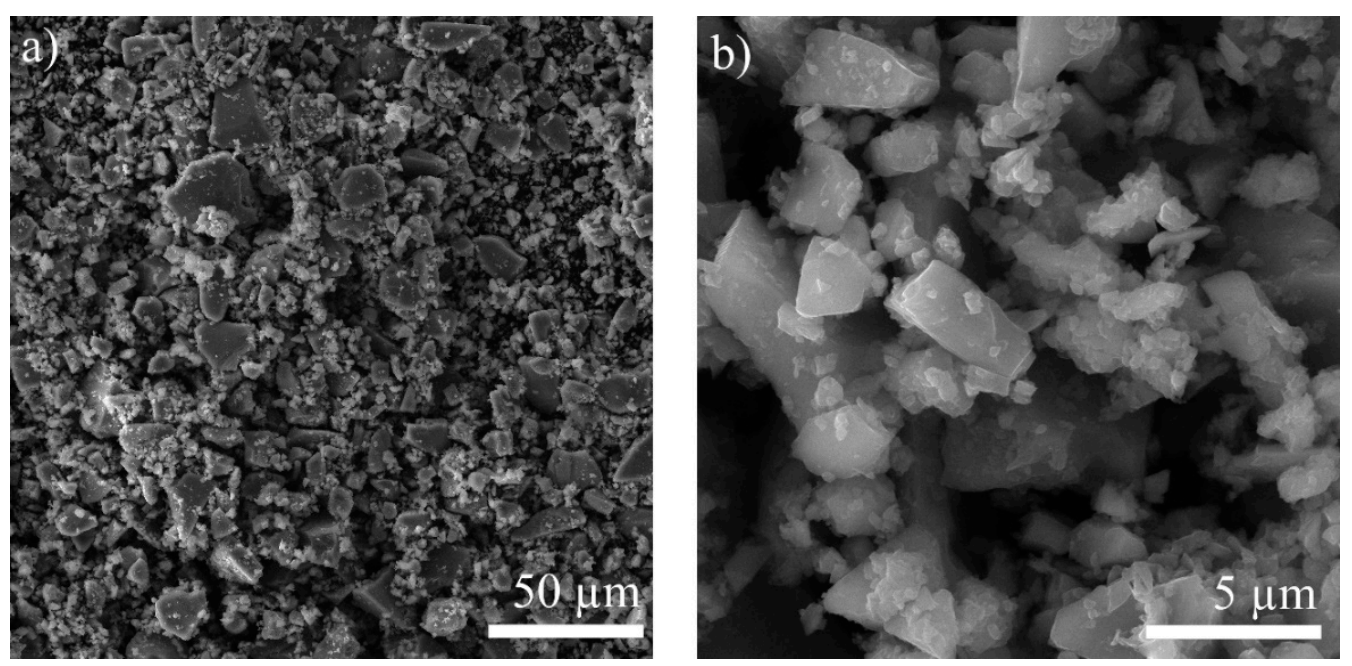

Figure 4. SEM images of milled Ecuadorian BMS in lower (a) and higher (b) magnifications.

The SEM images of the P-180 sample, which underwent the pre-treatment, are shown in Figure 5. This powder resulted in two different morphologies, flower-like microparticles and aggregates of nanoparticles, marked in Figure 5a as regions 1 and 2, respectively. A few micronic particles of remaining precursor were also identified (Figure $5 \mathrm{a}$, pointed by arrow 3). This overall morphology was confirmed in different areas of the P-180 sample (Figure S2). Flower-shape morphologies had diameters in the 2-6 $\mu \mathrm{m}$ range (Figure S3a), and were composed of thin, smooth sheet-like nanopetals (see Figure $5 b$ ), which were about 15-50 nm thick (Figure S3b). EDS mapping confirmed homogenous Fe-rich composition of flower-like architectures (Figure S4), exhibiting an Fe/Ti mass ratio of $\sim 4.3$ (Table S2), as demonstrated by EDS analysis. Regarding the aggregates (see Figure 5c), they were constituted of Ti-rich nanoparticles of 40 to $125 \mathrm{~nm}$ (Figures S5 and S6), with an Fe/Ti mass ratio of $\sim 0.7$ (Table S3). It is worth noting that for both morphologies, the presence of sodium was detected, arising from the alkaline hydrothermal treatment. Nanoparticle aggregates were 2.5 times richer in Na compared to the flower-like morphology (Tables S2 and S3).

SEM images of the products synthetized without pre-treatment (sample 180) are presented in Figure 6. A mixture of nanobelts and plate-like particles (flat chunks) was obtained under this procedure (Figure 6a). The presence of the described morphologies was verified in several regions of the 180 sample (Figure S7). The nanobelts were arranged in bundles (Figure 6b). Individual nanobelts had typical widths of 20 to $125 \mathrm{~nm}$ (Figure S8), while the lengths were submicronic. The nanobelts had a higher Ti content (Figure S9) than plate-like particles, resulting in an Fe/Ti mass ratio of $~ 1.6$ (Table S4). Plate-like particles are presented in Figure 6c. These were Fe-rich structures (Figure S10) as demonstrated by the Fe/Ti mass ratio of $\sim 4.6$ (Table S5). It should be noted that sodium was also detected in the 180 products, and ascribed to the alkaline hydrothermal reaction. The nanobelts exhibited a Na content three times higher than the plate-like particles. Likewise, scarce remaining fragments of the precursor were also identified.

Complete SEM-EDS data of milled BMS and all identified morphologies in P-180 and 180 powders are detailed in the Supplementary Material (Figures S1-S10, and Tables S1-S5). $\mathrm{Fe}, \mathrm{Ti}$, and Na EDS mapping is also depicted for each morphology, as well as the corresponding EDS spectrum. 

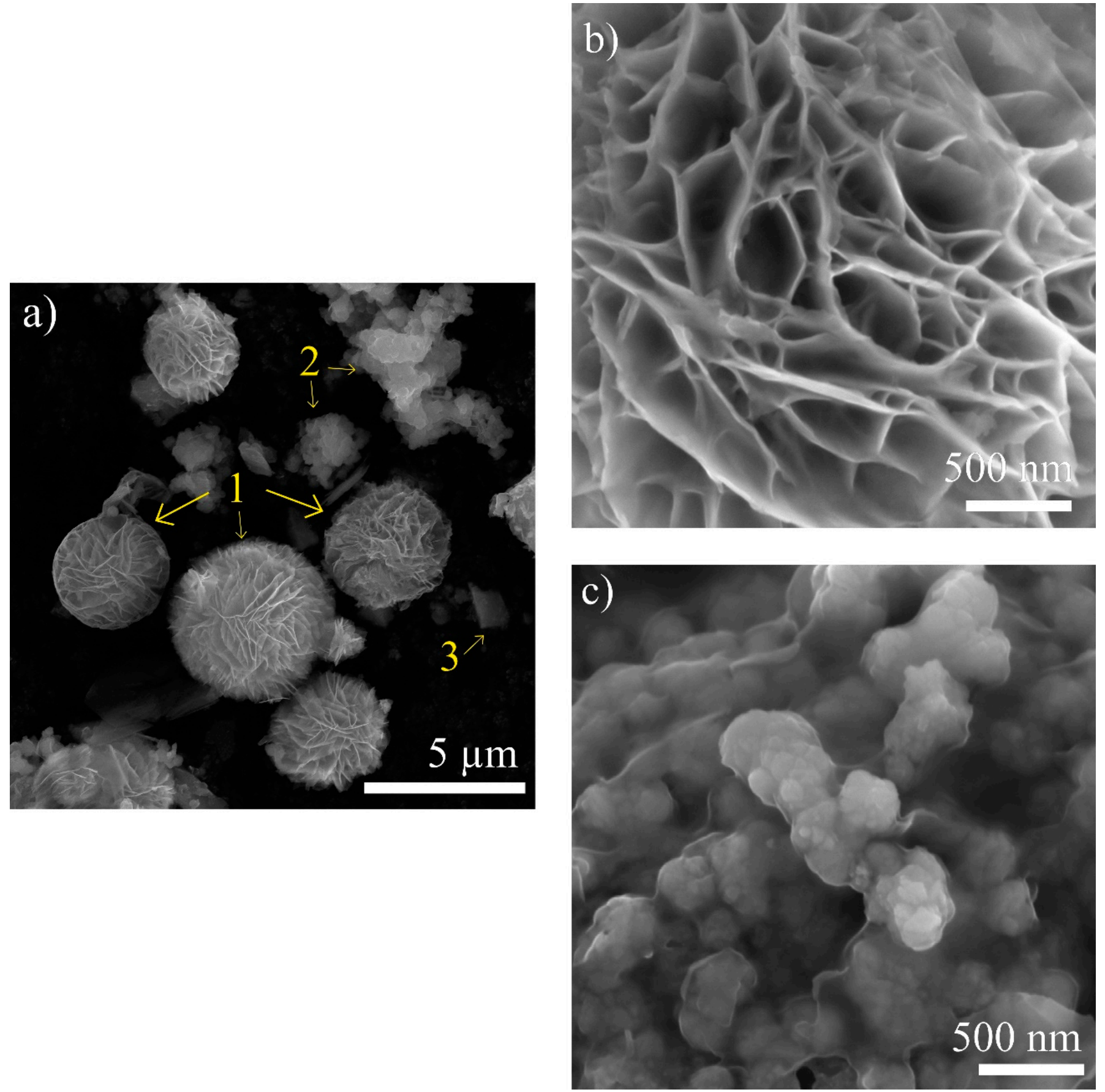

Figure 5. SEM images of the (a) P-180 product illustrating both morphologies, (b) flower-like architecture and (c) aggregates of nanoparticles.

\subsection{TEM Analysis}

TEM images of products P-180 and 180 are shown in Figures 7 and 8, respectively. The morphologies distinguished by SEM were confirmed by TEM. Nanosheet-assembled flowers (Figure 7a,b) and nanoparticle agglomerates (Figure 7c) were identified in P-180, while 180 powder was comprised of a mixture of nanobelts (Figure 8a) and plate-like particles (Figure $8 b, c$ ), as stated before. 

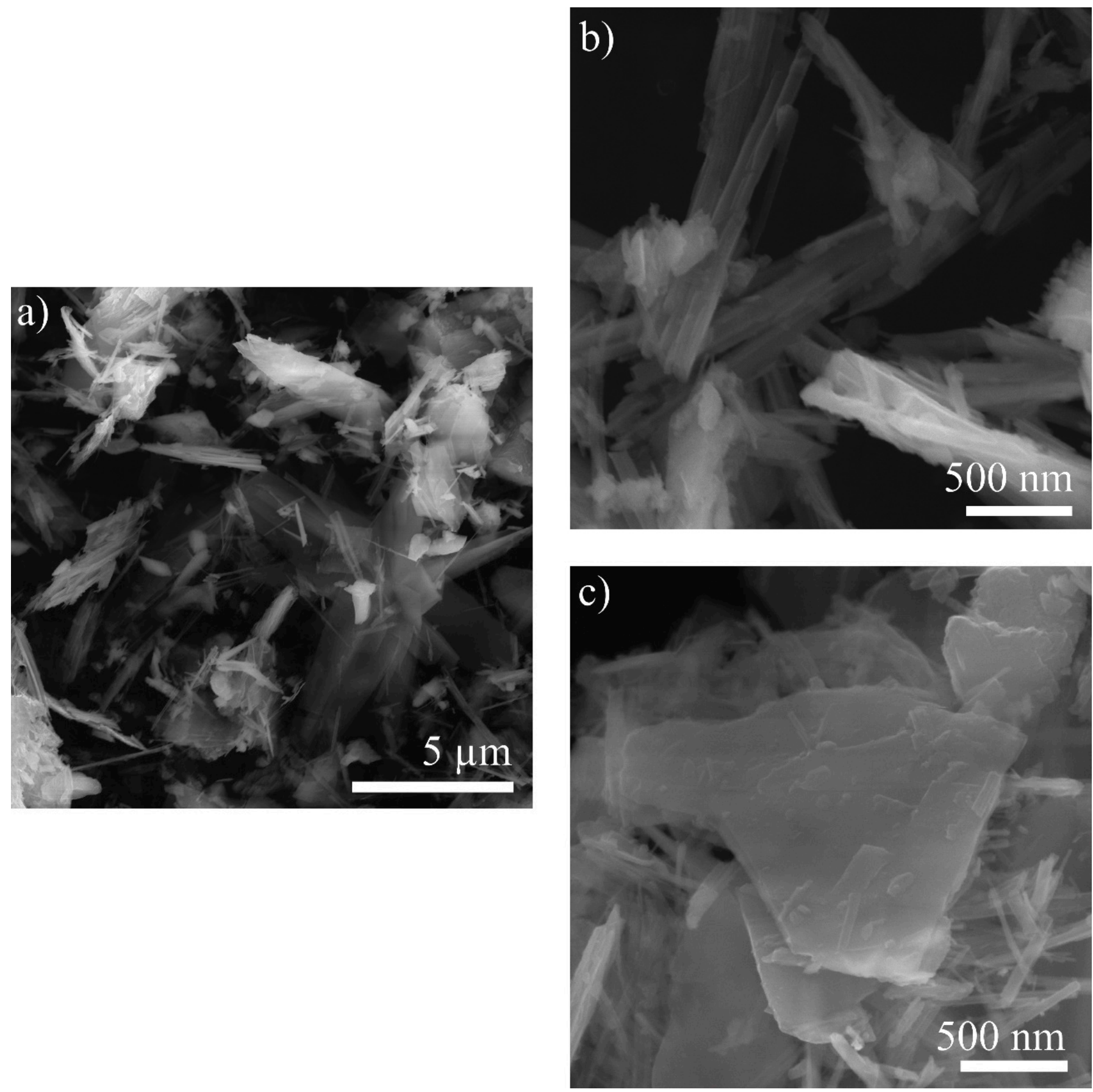

Figure 6. SEM images of (a) the 180 product illustrating both morphologies, (b) nanobelts and (c) plate-like particles. 

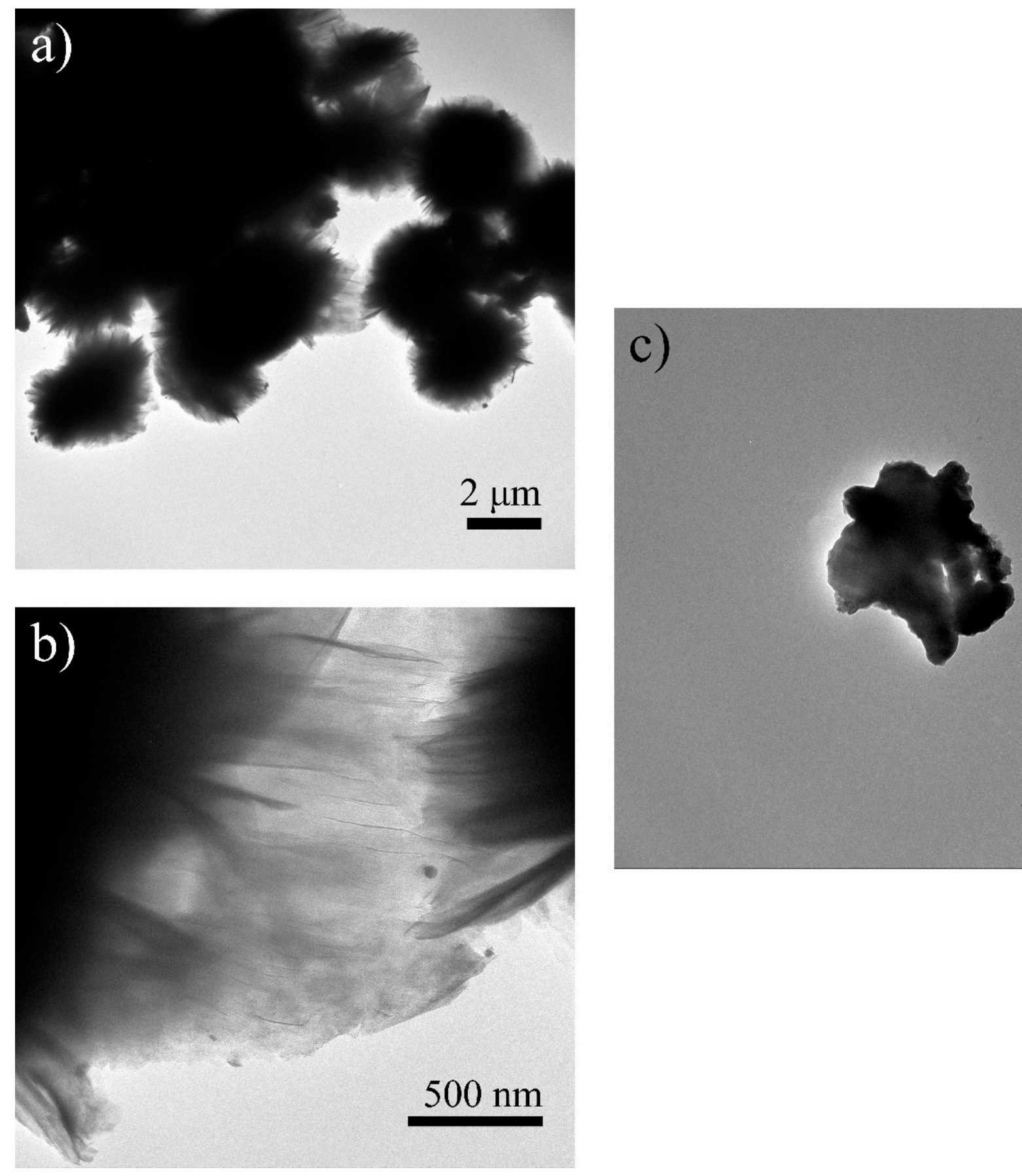

$500 \mathrm{~nm}$

Figure 7. TEM images of P-180 synthetized products: (a) and (b) flower-like morphology, and (c) nanoparticles agglomerate.

\subsection{Gas Sorption Analysis}

The specific surface area of milled BMS, and P-180 and 180 powders were 20.7, 26.3, and $18 \mathrm{~m}^{2} \mathrm{~g}^{-1}$, respectively. The corresponding $\mathrm{N}_{2}$ adsorption isotherms are shown in the Supplementary Material (Figures S11-S13). 

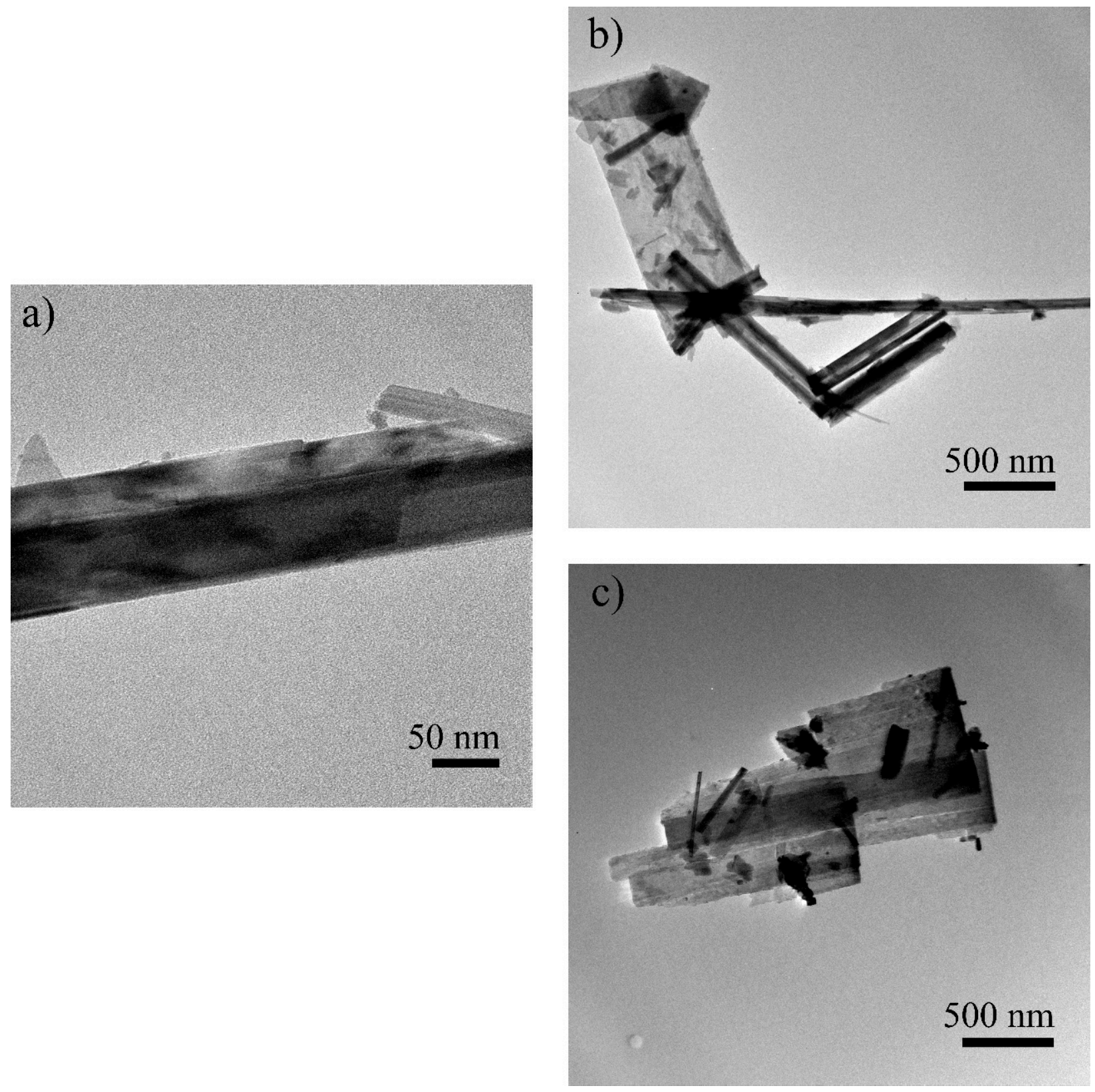

Figure 8. TEM images of 180 synthetized products: (a) nanobelts, (b) and (c) a mixture of nanobelts/plate-like particles.

\section{Discussion}

Raw unmilled Ecuadorian BMS were thoroughly characterized in our previous work [5]. The unit-cell volume and the mean crystallite size of the unmilled BMS used in the current study were calculated as being 308.40(6) $\AA^{3}$ and $105.8(3.8) \mathrm{nm}$, respectively, in accordance to the previously reported data [5]. As expected, after milling process no chemical modification occurred within IH-SS and, therefore, the unit-cell volume of milled BMS did not significantly change; i.e., the value of 308.51(7) $\AA^{3}$ (see Table 2) is within the standard deviation with the above calculated value for the unmilled sand.

It is well-known that the main crystalline phase in BMS corresponds to IH-SS with trace amounts of orthoclase feldspar and zircon [5]. Brown and co-workers [34] studied IH-SS with different phase compositions, from hematite to ilmenite-rich end. They plotted the unit-cell volumes of different IH-SS phases as a function of the ilmenite molar fraction $\left(\mathrm{x}_{\mathrm{ilm}}\right)$. Thus, this approach was considered in the current study to estimate the ilmenite 
content within IH-SS in the milled BMS and in the as-synthetized powders. Furthermore, the ilmenite-hematite molar fractions and the estimated Fe/Ti mass ratio are presented in Table 3 . The $\mathrm{Fe} / \mathrm{Ti}$ mass ratio was estimated by replacing the corresponding $\mathrm{x}_{\mathrm{ilm}}$ and $\mathrm{x}_{\text {hem }}$ in the formula $\left(\mathrm{x}_{\mathrm{ilm}}\right) \mathrm{FeTiO}_{3} \cdot\left(\mathrm{x}_{\mathrm{hem}}\right) \mathrm{Fe}_{2} \mathrm{O}_{3}$. This methodology gives a good approximation to determine the phase composition, since the calculated formula of (0.53) $\mathrm{FeTiO}_{3} \cdot(0.47) \mathrm{Fe}_{2} \mathrm{O}_{3}$ is very close to the reported for Ecuadorian BMS (0.6) $\mathrm{FeTiO}_{3} \cdot(0.4) \mathrm{Fe}_{2} \mathrm{O}_{3}$, from data of the semiquantitative X-ray fluorescence [5].

Table 3. Ilmenite and hematite molar fractions within the ilmenite-hematite solid solution, obtained by XRPD, in milled BMS, and P-180 and 180 powders, together with estimated Fe/Ti mass ratios.

\begin{tabular}{cccc}
\hline Samples & $\begin{array}{c}\text { Ilmenite } \\
\text { Molar Fraction } \\
\left(\mathbf{x}_{\mathbf{i l m})}\right)\end{array}$ & $\begin{array}{c}\text { Hematite } \\
\text { Molar Fraction } \\
\left(\mathbf{x}_{\mathbf{h e m}}\right)\end{array}$ & $\begin{array}{c}\text { Estimated } \\
\text { Fe/Ti } \\
\text { Mass Ratio }\end{array}$ \\
\hline Milled BMS & 0.53 & 0.47 & 3.2 \\
P-180 & 0.34 & 0.66 & 5.7 \\
180 & 0.40 & 0.60 & 4.7 \\
\hline
\end{tabular}

It is worth noting that the estimated $\mathrm{Fe} / \mathrm{Ti}$ mass ratios of the products synthesized in this work (Table 3) are greater than those reported in literature (see Table 1). The high Fe contents indicates that the chemical composition of the obtained IH-SS significantly differs from that of other nanostructures prepared using ilmenite-based sands [12-14,30]. On the other hand, Table 4 shows a summary of Fe/Ti mass ratios of each identified morphology based on semiquantitative EDS analyses. As can be observed, the Fe/Ti mass ratio of milled BMS estimated from unit-cell volume is in good agreement with the value calculated from EDS data.

Table 4. Fe/Ti mass ratio obtained by semiquantitative EDS analyses for milled BMS and each morphology within the as-synthetized powders.

\begin{tabular}{ccc}
\hline Samples & Morphology & $\begin{array}{c}\text { Fe/Ti } \\
\text { Mass Ratio }\end{array}$ \\
\hline Milled BMS & Micron-size agglomerates & 3.1 \\
\hline \multirow{2}{*}{ P-180 } & Flower-like microparticles & 4.3 \\
& Aggregates of nanoparticles & 0.7 \\
& Remaining precursor & 2.7 \\
\hline \multirow{2}{*}{180} & Nanobelts & 1.6 \\
& Plate-like particles & 4.6 \\
\hline
\end{tabular}

It is also evident that after alkaline hydrothermal treatments (samples P-180 and 180), the IH-SS products became richer in hematite molar fraction than the precursor (see Table 3) and, therefore, richer in Fe content than the IH-SS in the milled BMS. The reduction of the calculated unit-cell for IH-SS in the samples P-180 and 180 (Table 2) and their much lower Ti content could be understood in terms of dissolution of IH-SS from the sand followed by precipitation of IH-SS in different nanosized morphologies (nanosheet-assembled flowers and nanobelts for P-180 and 180 samples, respectively). In the case of P-180 powder, the values of $x_{i l m}$ and $x_{\text {hem }}$ indicate that the newly precipitated IH-SS phase, the one forming flower-like morphology, is close to the hematite-rich end of IH-SS (see Table 3). The dissolution-precipitation mechanism of IH-SS during the hydrothermal synthesis from ilmenite mineral sands was previously suggested by Tao et al. [30].

Besides the precipitated IH-SS phases rich in hematite, both P-180 and 180 presented additional diffraction lines belonging to a secondary phase. The low number of these lines, together with their low intensities and broad aspect made difficult their refinement by the Le Bail method. However, their chemical composition, rich in sodium, and previous 
knowledge of the phases precipitated during hydrothermal treatment of ilmenite mineral sands $[12,14,28,35]$, suggested that the lines situated especially at $11.31^{\circ}, 26.18^{\circ}, 30.05^{\circ}$, $38.20^{\circ}$, and $47.62^{\circ} 2 \theta$ in the XRPD pattern of P-180 powder (Figure $3 \mathrm{~b}$ ) might belong to a corrugated sodium trititanate structure (PDF: 00-031-1329) with some Ti being exchange for Fe.

In respect of 180 powder, IH-SS exhibited a higher Fe/Ti mass ratio (4.7) than the milled BMS (Table 3), suggesting that the precipitated IH-SS is closer to the hematite-rich side than the precursor, but less in comparison to P-180. This value is practically equal to the Fe/Ti mass ratio of the plate-like particles (4.6), as can be observed in Table 4, indicating that plate-like particles belong to IH-SS. On the other hand, the Fe/Ti mass ratio of the scarce remaining precursor particles was kept practically equal to 3.0 as in the milled BMS. An additional analysis of the diffraction lines $\left(12.34^{\circ}, 18.35^{\circ}, 30.04^{\circ}, 36.74^{\circ}\right.$, and $43.35^{\circ}$ $2 \theta$ ), that do not belong to IH-SS might be associated with a sodium hexatitanate structure (PDF: 01-073-1398), which is also an Fe-doped compound. These diffraction lines can be attributed to nanobelts, with an Fe/Ti mass ratio of 1.6 (see Table 4).

The proposed dissolution-precipitation mechanism will be further investigated through a time-dependent analysis to understand the evolution of these morphologies, during pretreatment and hydrothermal stages. Likewise, with respect to the P-180 sample, to elucidate the formation mechanism of the flower-like particles and nanoparticle agglomerates, their growth should be monitored at different stages of the pre-treatment and during the alkaline hydrothermal synthesis. It is important to highlight that the formation mechanism of the as-synthesized products is beyond the scope of this work.

With regard to the textural properties, the specific surface area of the P-180 sample increased $27 \%$ when compared to the precursor. Conversely, the 180 powder showed a lower specific surface area than the milled BMS. It is worth noting that the specific surface area not only depends on the size and morphology of the primary particles, but also on the agglomeration degree of the powders [36]. Hence, less agglomerated powders adsorb more $\mathrm{N}_{2}$ molecules during BET analysis, exhibiting higher specific surface area. Therefore, the results of BET surface area can be attributed to the three previously mentioned factors suggesting that P-180 powder is less agglomerated than 180 sample. Besides, the morphologies observed in the P-180 sample were assembled by nanosized structures (thin nanopetals within flower-like particles, and nanoparticles within agglomerates). This could explain the higher specific surface area of the P-180 powder compared to that of the milled precursor.

The performed characterizations were intended to prove the feasibility of synthesizing iron-titanium oxide nanostructures (Fe-Ti-NS) from an alternative mineral precursor. Finally, it is important to point out that the as-synthesized products could be potentially employed as novel nanomaterials in several fields such as purification technologies [37,38], pigments [39], and as reinforcements of polymer composites [40,41]. Indeed, Fe-Ti-NS can be used as photocatalysts since they are expected to absorb in the visible region of the electromagnetic spectrum, based on its phase composition [41]. Furthermore, considering the reddish and brown colors of the obtained powders, they can be used in the field of inorganic pigments [42]. Likewise, to improve the corrosion resistance of polymer coatings deposited on metal surface, Fe-Ti-NS could be employed as fillers, as in the case of iron or titanium oxide nanoparticles [43,44]. Lastly, the incorporation of the Fe-Ti-NS into a polymer could enhance the mechanical and thermal properties of the matrix [45], as an alternative to carbon-based nanostructures.

\section{Conclusions}

We have demonstrated the viability of obtaining iron-titanium oxide nanostructures from milled Ecuadorian BMS as a low-cost precursor. The mineral processing was conducted through an alkaline hydrothermal synthesis using $\mathrm{NaOH} 10 \mathrm{M}$ at $180{ }^{\circ} \mathrm{C}$ for $72 \mathrm{~h}$, under stirring. The resulting products encompassed nanobelts and plate-like particles (180 sample) in just one single step during a few days at a low temperature, which is an advantage over other synthesis routes. On the other hand, with the incorporation of a 
pre-treatment ( $\mathrm{NaOH} 10 \mathrm{M}, 180{ }^{\circ} \mathrm{C}, 28 \mathrm{~h}$ under stirring, followed by $\sim 1$ month aging), flower-like architectures and nanoparticle aggregates were synthesized (P-180 sample). In both cases, the resulting powders were composed of hematite-rich IH-SS (ilmenite-hematite solid solutions) together with a lower amount of a secondary phase, which might belong to corrugated sodium titanate structures. Besides, the flower-like morphology within the P-180 sample and the plate-like particles in the 180 sample were Fe-rich structures, while nanoparticle aggregates in the P-180 powder, and nanobelts in the 180 powder, exhibited high Ti contents.

Despite the longer time involved, the pre-treatment drastically changed the physical, chemical, and morphological features of the as-synthetized powders. The specific surface area of the P-180 sample increased in $27 \%$ compared with the precursor, which is an important issue for applications such as photocatalysts or reinforcements of composites. Although there is still a lot of room for improvement, specifically to elucidate the formation mechanism of nanostructures, this initial development showed a promising route for obtaining nanostructures directly from chemically unrefined Ecuadorian mineral resources. This could result in higher added-value products for a variety of promising applications.

Supplementary Materials: The following are available online at https:/ /www.mdpi.com/2075-163 X/11/2/122/s1, Figure S1: EDS spectrum of milled BMS, Figure S2: SEM images of P-180 powder illustrating flower-like architectures and aggregates of nanoparticle morphologies, Figure S3: Size measurements in P-180 powder of (a) flower-like morphologies and its (b) nanopetals, Figure S4: EDS mapping and spectrum of flower-like morphology identified in P-180 powder, Figure S5: Size measurements in P-180 powder of nanoparticles within agglomerates, Figure S6: EDS mapping and spectrum of aggregate nanoparticles identified in P-180 powder, Figure S7: SEM images of 180 powder illustrating nanobelts and plate-like particle morphologies, Figure S8: Size measurements of nanobelts typical widths in 180 powder, Figure S9: EDS mapping and spectrum of nanobelts identified in 180 powder, Figure S10: EDS mapping and spectrum of plate-like particles identified in 180 powder, Figure S11: $\mathrm{N}_{2}$ adsorption isotherm of milled BMS, acquired in the BET range of $\mathrm{P} / \mathrm{Po}=0.05-0.3$ (correlation coefficient $=0.999959)$, Figure S12: $\mathrm{N}_{2}$ adsorption isotherm of P-180 powder, acquired in the BET range of $\mathrm{P} / \mathrm{Po}=0.05-0.3$ (correlation coefficient $=0.999920$ ), Figure S13: $\mathrm{N}_{2}$ adsorption isotherm of 180 powder, acquired in the BET range of $\mathrm{P} / \mathrm{Po}=0.05-0.3$ (correlation coefficient $=0.999984$ ), Table S1: EDS semiquantitative elemental analysis of milled BMS, Table S2: EDS semiquantitative elemental analysis of flower-like morphology identified in P-180 powder, Table S3: EDS semiquantitative elemental analysis of aggregate nanoparticles identified in P-180 powder, Table S4: EDS semiquantitative elemental analysis of nanobelts identified in 180 powder, Table S5: EDS semiquantitative elemental analysis of plate-like particles identified in 180 powder.

Author Contributions: Conceptualization, K.J.L., B.A.M., V.H.G., E.P. and P.I.P.; Investigation, K.J.L., B.A.M., A.D., K.V., V.H.G., E.P. and P.I.P.; Methodology, K.J.L., V.H.G., E.P. and P.I.P.; Supervision, V.H.G., E.P. and P.I.P.; Writing—original draft, K.J.L., B.A.M. and P.I.P.; Writing—review \& editing, K.J.L., B.A.M., A.D., K.V., V.H.G., E.P. and P.I.P. All authors have read and agreed to the published version of the manuscript.

Funding: This research received no external funding.

Data Availability Statement: The data presented in this study are available in article or supplementary material.

Acknowledgments: The authors are grateful to EPN (project grant PIJ-18-01). The authors also acknowledge M. J. Benitez for XRPD analyses (Electroceramics Laboratory, Department of Physics, EPN); P. Romero and O. Campaña for gas sorption analyses (New Materials Laboratory-LANUM, Department of Materials, EPN). B.A.M. is grateful to CNPq (National Council for Scientific and Technological Development) for a Research Productivity Grant.

Conflicts of Interest: The authors declare no conflict of interest. 


\section{References}

1. Hou, B.; Keeling, J.; Van Gosen, B.S. Geological and Exploration Models of Beach Placer Deposits, Integrated from Case-Studies of Southern Australia. Ore Geol. Rev. 2017, 80, 437-459. [CrossRef]

2. Da Silva, M.A.M. Provenance of heavy minerals in beach sands, southeastern Brazil: From Rio Grande to Chui (Rio Grande do Sul State). Sediment. Geol. 1979, 24, 133-148. [CrossRef]

3. Abdel-Karim, A.A.M.; Zaid, S.M.; Moustafa, M.I.; Barakat, M.G. Mineralogy, chemistry and radioactivity of the heavy minerals in the black sands, along the northern coast of Egypt. J. Afr. Earth Sci. 2016, 123, 10-20. [CrossRef]

4. Sundararajan, M.; Bhat, K.H.; Velusamy, S.; Babu, N.; Janaki, M.E.K.; Sasibhooshanan, S.; Das, P.N.M. Characterization of Ilmenite from Kerala Coastline, India: Implications in the Production of Synthetic Rutile. J. Miner. Mater. Charact. Eng. 2009, 8, 427-438. [CrossRef]

5. Lagos, K.J.; Marinkovic, B.A.; Dosen, A.; Guamán, M.V.; Guerrero, V.H.; Pardo, E.; Pontón, P.I. Data on phase and chemical compositions of black sands from "El Ostional" beach situated in Mompiche, Ecuador. Data Br. 2020, 32, 106214. [CrossRef]

6. Gázquez, M.J.; Bolívar, J.P.; Garcia-Tenorio, R.; Vaca, F. A Review of the Production Cycle of Titanium Dioxide Pigment. Mater. Sci. Appl. 2014, 5, 441-458. [CrossRef]

7. Fray, D.J. Novel methods for the production of titanium. Int. Mater. Rev. 2008, 53, 317-325. [CrossRef]

8. Muwanguzi, A.J.B.; Karasev, A.V.; Byaruhanga, J.K.; Jönsson, P.G. Characterisation of the Physical and Metallurgical Properties of Natural Iron Ore for Iron Production. ISRN Mater. Sci. 2012, 2012, 1-9. [CrossRef]

9. Yousef, L.A. Uranium Adsorption Using Iron-Titanium Mixed Oxides Separated from Ilmenite Mineral, Black Sands, Rosetta, Egypt. Arab J. Nucl. Sci. Appl. 2017, 50, 43-57.

10. Cañas-Martínez, D.M.; Gauthier, G.H.; Pedraza-Avella, J.A. Photo-oxidative and photo-reductive capabilities of ilmenite-rich black sand concentrates using methyl orange as a probe molecule. Photochem. Photobiol. Sci. 2019, 18, 912-919. [CrossRef]

11. Yu, J.; Chen, Y.; Glushenkov, A.M. Titanium Oxide Nanorods Extracted from Ilmenite Sands. Cryst. Growth Des. 2009, 9, 1240-1244. [CrossRef]

12. Jardim, P.M.; Mancic, L.; Marinkovic, B.A.; Milosevic, O.; Rizzo, F. $\mathrm{Na}_{x-y} \mathrm{H}_{\mathrm{y}} \mathrm{Ti}_{2-x} \mathrm{Fe}_{\mathrm{x}} \mathrm{O}_{4} \cdot \mathrm{nH}_{2} \mathrm{O}$ nanosheets with lepidocrocite-like layered structure synthesized by hydrothermal treatment of ilmenite sand. Cent. Eur. J. Chem. 2011, 9, 415-421. [CrossRef]

13. Marinkovic, B.A.; Mancic, L.; Jardim, P.M.; Milosevic, O.; Rizzo, F. Hydrothermal synthesis of $\mathrm{Na}_{\mathrm{x}} \mathrm{Fe}_{\mathrm{x}} \mathrm{Ti}_{2-\mathrm{x}} \mathrm{O}_{4}$ from natural ilmenite sand: $\mathrm{A} \mathrm{CaFe}_{2} \mathrm{O}_{4}$ structure type compound. Solid State Commun. 2008, 145, 346-350. [CrossRef]

14. Costa, A.M.L.M.; Marinkovic, B.A.; Suguihiro, N.M.; Smith, D.J.; Da Costa, M.E.H.M.; Paciornik, S. Fe-doped nanostructured titanates synthesized in a single step route. Mater. Charact. 2015, 99, 150-159. [CrossRef]

15. Sangaiya, P.; Jayaprakash, R. A Review on Iron Oxide Nanoparticles and Their Biomedical Applications. J. Supercond. Nov. Magn. 2018, 31, 3397-3413. [CrossRef]

16. Sharma, G.; Kumar, A.; Sharma, S.; Naushad, M.; Prakash Dwivedi, R.; ALOthman, Z.A.; Mola, G.T. Novel development of nanoparticles to bimetallic nanoparticles and their composites: A review. J. King Saud Univ. Sci. 2019, 31, 257-269. [CrossRef]

17. Haider, A.J.; Jameel, Z.N.; Al-Hussaini, I.H.M. Review on: Titanium Dioxide Applications. Energy Procedia 2019, 157, 17-29. [CrossRef]

18. Nasirian, M.; Lin, Y.P.; Bustillo-Lecompte, C.F.; Mehrvar, M. Enhancement of photocatalytic activity of titanium dioxide using non-metal doping methods under visible light: A review. Int. J. Environ. Sci. Technol. 2018, 15, 2009-2032. [CrossRef]

19. Çeşmeli, S.; Biray Avci, C. Application of titanium dioxide $\left(\mathrm{TiO}_{2}\right)$ nanoparticles in cancer therapies. J. Drug Target. 2019, 27, 762-766. [CrossRef]

20. Bhateria, R.; Singh, R. A review on nanotechnological application of magnetic iron oxides for heavy metal removal. J. Water Process Eng. 2019, 31, 100845. [CrossRef]

21. Nasr, M.; Eid, C.; Habchi, R.; Miele, P.; Bechelany, M. Recent Progress on Titanium Dioxide Nanomaterials for Photocatalytic Applications. ChemSusChem 2018, 11, 3023-3047. [CrossRef]

22. Simpraditpan, A.; Wirunmongkol, T.; Pavasupree, S.; Pecharapa, W. Simple hydrothermal preparation of nanofibers from a natural ilmenite mineral. Ceram. Int. 2013, 39, 2497-2502. [CrossRef]

23. Simpraditpan, A.; Wirunmongkol, S.; Pavasupree, S.; Pecharapa, W. Preparation and Characterization of Titanate Nanofibers from Low-Cost Natural Ilmenite Sand. In Proceedings of the 10th Eco-Energy and Materials Science and Engineering Symposium, Muang, Ubon-ratchathani, Thailand, 5-8 December 2012.

24. Kotova, O.B.; Ponaryadov, A.V.; Gömze, L.A. Hydrothermal synthesis of $\mathrm{TiO}_{2}$ nanotubes from concentrate of titanium ore of Pizhemskoe deposit (Russia). Vestn. Inst. Geol. Komi Sci. Cent. Ural Branch RAS 2016, 1, 34-36. [CrossRef]

25. Suzuki, Y.; Pavasupree, S.; Yoshikawa, S.; Kawahata, R. Natural rutile-derived titanate nanofibers prepared by direct hydrothermal processing. J. Mater. Res. 2005, 20, 1063-1070. [CrossRef]

26. Suzuki, Y.; Pavasupree, S.; Yoshikawa, S.; Kawahata, R. Direct Hydrothermal Processing of Long Titanate Nanofibers from Natural Rutile. Key Eng. Mater. 2006, 317-318, 243-246. [CrossRef]

27. Pavasupree, S.; Suzuki, Y.; Yoshikawa, S.; Kawahata, R. Synthesis of titanate, $\mathrm{TiO}_{2}$ (B), and anatase $\mathrm{TiO}_{2}$ nanofibers from natural rutile sand. J. Solid State Chem. 2005, 178, 3110-3116. [CrossRef]

28. Mancic, L.T.; Marinkovic, B.A.; Jardim, P.M.; Milosevic, O.B.; Rizzo, F. Precursor Particle Size as the Key Parameter for Isothermal Tuning of Morphology from Nanofibers to Nanotubes in the $\mathrm{Na}_{2-x} \mathrm{H}_{x} \mathrm{Ti}_{n} \mathrm{O}_{2 n+1}$ System through Hydrothermal Alkali Treatment of Rutile Mineral Sand. Cryst. Growth Des. 2009, 9, 2152-2158. [CrossRef] 
29. Kawahata, R.; Suzuki, Y. Mineral sand as a low cost source of nanomaterials. Key Eng. Mater. 2006, 317-318, 739-742. [CrossRef]

30. Tao, T.; Glushenkov, A.M.; Liu, H.; Liu, Z.; Dai, X.J.; Chen, H.; Ringer, S.P.; Chen, Y. Ilmenite FeTiO 3 nanoflowers and their pseudocapacitance. J. Phys. Chem. C 2011, 115, 17297-17302. [CrossRef]

31. Ministerio de Minería del Ecuador. Plan Nacional de Desarrollo Del Sector Minero. Available online: http://historico.mineria. gob.ec/plan-nacional-de-desarrollo-del-sector-minero (accessed on 8 December 2020).

32. Marinkovic, B.A.; Pontón, P.I.; Resende, J.M.; Letichevsky, S.; Habran, M.; Viol, J.B.; Pandoli, O.; Mancic, L. Lepidocrocite-like ferrititanate nanosheets and their full exfoliation with quaternary ammonium compounds. Mater. Des. 2015, 85, 197-204. [CrossRef]

33. Ginley, D.S.; Butler, M.A. The photoelectrolysis of water using iron titanate anodes. J. Appl. Phys. 1977, 48, 2019-2021. [CrossRef]

34. Brown, N.E.; Navrotsky, A.; Nord, G.L.; Banerjee, S.K. Hematite-ilmenite $\left(\mathrm{Fe}_{2} \mathrm{O}_{3}-\mathrm{FeTiO}_{3}\right)$ solid solutions: Determinations of Fe-Ti order from magnetic properties. Am. Mineral. 1993, 78, 941-951.

35. Morgado, E.; De Abreu, M.A.S.; Pravia, O.R.C.; Marinkovic, B.A.; Jardim, P.M.; Rizzo, F.C.; Araújo, A.S. A study on the structure and thermal stability of titanate nanotubes as a function of sodium content. Solid State Sci. 2006, 8, 888-900. [CrossRef]

36. Walter, D.; Berges, M.; Kreyling, W.; Korinth, G.; Drexler, H.; Landsiedel, R.; Heinrich, U.; Hartwig, A.; Schins, R.; Pauluhn, J.; et al. Nanomaterials; Wiley-VCH: Bonn, Germany, 2013; Chapter 1; pp. 19-24.

37. Tada, H.; Jin, Q.; Nishijima, H.; Yamamoto, H.; Fujishima, M.; Okuoka, S.; Hattori, T.; Sumida, Y.; Kobayashi, H. Titanium(IV) Dioxide Surface-Modified with Iron Oxide as a Visible Light Photocatalyst. Angew. Chem. 2011, 123, 3563-3567. [CrossRef]

38. Chen, Y.H.; Li, F.A. Kinetic study on removal of copper(II) using goethite and hematite nano-photocatalysts. J. Colloid Interface Sci. 2010, 347, 277-281. [CrossRef]

39. Müller, M.; Villalba, J.C.; Mariani, F.Q.; Dalpasquale, M.; Lemos, M.Z.; Huila, M.F.G.; Anaissi, F.J. Synthesis and characterization of iron oxide pigments through the method of the forced hydrolysis of inorganic salts. Dye Pigments 2015, 120, 271-278. [CrossRef]

40. El-Sayed Abdo, A.; El-Sarraf, M.A.; Gaber, F.A. Utilization of ilmenite/epoxy composite for neutrons and gamma rays attenuation. Ann. Nucl. Energy 2003, 30, 175-187. [CrossRef]

41. Longo, A.; Wang, X.L.; Ruotolo, A.; Peluso, A.; Carotenuto, G.; Lortz, R. Effect of the polymeric matrix on the structural and magnetic properties of hematite/polymer composites. J. Nanopart. Res. 2012, 14, 1314. [CrossRef]

42. Walter, D. Characterization of synthetic hydrous hematite pigments. Thermochim. Acta 2006, 445, 195-199. [CrossRef]

43. Abdou, M.I.; Ayad, M.I.; Diab, A.S.M.; Hassan, I.A.; Fadl, A.M. Studying the corrosion mitigation behavior and chemical durability of $\mathrm{FeTiO}_{3} /$ melamine formaldehyde epoxy composite coating for steel internal lining applications. Prog. Org. Coat. 2019, 133, 325-339. [CrossRef]

44. Abdou, M.I.; Ayad, M.I.; Diab, A.S.M.; Hassan, I.A.; Fadl, A.M. Influence of surface modified ilmenite/melamine formaldehyde composite on the anti-corrosion and mechanical properties of conventional polyamine cured epoxy for internal coating of gas and oil transmission pipelines. Prog. Org. Coat. 2017, 113, 1-14. [CrossRef]

45. Tjong, S.C. Structural and mechanical properties of polymer nanocomposites. Mater. Sci. Eng. R 2006, 53, 73-197. [CrossRef] 